\title{
Legal Implications of Dismantling UNRWA: A European Perspective
}

\author{
Mais Qandeel ${ }^{1} \&$ Sarah Progin-Theuerkauf ${ }^{2}$ \\ ${ }^{1}$ Assistant Professor of international law, School of Law, Örebro University, Sweden \\ ${ }^{2}$ Professor, University of Fribourg, Switzerland
}

Received: March 2, 2021

doi:10.5539/jpl.v14n3p84

\author{
Accepted: April 6, $2021 \quad$ Online Published: April 6, 2021 \\ URL: https://doi.org/10.5539/jpl.v14n3p84
}

\begin{abstract}
Palestine refugees are excluded from the scope of the international refugee protection system. The agency that is currently protecting them, UNRWA, is under threat. What would the end of UNRWA mean at the European level? This article explains the special situation of Palestinians, the history and role of UNRWA and the consequences that a dissolution of UNRWA would entail. It analyses the situation from an EU perspective, as the CJEU has already delivered several landmark judgments. The article concludes that an abolition of UNRWA would place Palestinians in a better position, as the European Union would be obliged to protect all those persons that currently fall under UNRWA's mandate and are hence excluded from obtaining refugee status. This is a finding that seems to be totally ignored or at least underestimated by the International Community. Nevertheless, the dissolution of UNRWA might lead to an unprecedented deterioration of the situation of Palestinians living in UNRWA's operating areas.
\end{abstract}

Keywords: Palestine refugees, EU, ipso facto protection, fundamental rights, EU Qualification Directive, CJEU

\section{Introduction}

In its 2019 Global Trends Report ${ }^{1}$, the United Nations High Commissioner for Refugees (UNHCR) indicated that, at the end of 2019, almost 79.5 million persons were forcibly displaced worldwide, of which 26 million persons are refugees. ${ }^{2}$ Of these refugees, 20.4 million persons were under the mandate of UNHCR. Approximately 5.6 million Palestinian refugees were under the mandate of the United Nations Relief and Work Agency for Palestine Refugees in the Near East (UNRWA or the Agency). ${ }^{3}$ According to the Palestine Resource Center for Palestinian Residency and Refugee Rights (Badil), by the end of 2018, "roughly 8.7 million (66.7 percent) of 13.05 million Palestinians worldwide were forcibly displaced persons. Among them are approximately 7.94 million Palestinian refugees and 760,000 IDPs [internal displaced persons]."

The special situation of "Palestine refugees/Palestinian refugees" has been at the centre of many studies and publications. ${ }^{6}$ However, so far, little has been said about the specific context of Europe and the status of Palestinians within the framework of the Common European Asylum System and its relation to UNRWA. In Europe, in recent times, certain politicians have asked for the abrogation of UNRWA. For instance, the Swiss Minister for Foreign Affairs, Ignazio Cassis, has expressed some doubts on the role of UNRWA. ${ }^{7}$ Some other States have stopped or threatened to stop financial funding to UNRWA. ${ }^{8}$ This could mean the end of UNRWA's

\footnotetext{
${ }^{1}$ UNHCR 'Global Trends: Forced Displacement in 2019' (2020)<https://www.unhcr.org/globaltrends2019/> accessed 9 October 2020

2 Ibid

${ }^{3}$ Ibid

${ }^{4}$ BADIL Resource Center for Palestinian Residency \& Refugee Rights 'Survey of Palestinian Refugees and Internally Displaced Persons' (2016-2018 Vol IX, xiv)

5 The term "Palestine refugees" refers to refugees under UNRWA's mandate, while "Palestinian refugees" refer to all those refugees of Palestinian origin. Palestine refugees, in a narrow sense, are persons belonging to different ethnicities and backgrounds who were displaced from Palestine between 1947-1949. Palestinian refugees, in a broader sense, are persons who were displaced from the territory corresponding to historic Palestine. See Lex Takkenberg and Francesca Albanese, Palestinian Refugees in International Law, (2nd ed., Oxford University Press 2020) 10-12

${ }^{6}$ Palestinian refugees - even more than other refugees - would actually like to return to their homeland but are not able to do so. Most of them would not qualify as refugees under Article 1 (A) of the 1951 Refugee Convention, as they are not individually persecuted.

7 SwissInfo.ch, 'Questions raised over UNRWA after Swiss-Israeli meeting, <https://www.swissinfo.ch/eng/palestinian-refugeeagency_questions-raised-over-unwra-after-swiss-israeli-meeting/45210084> accessed on 9 October 2020

${ }^{8}$ For more information about States funding to UNRWA $<$ https://www.unrwa.org/unrwa-fund $>$ accessed 9 October 2020
} 
mandate. But what exactly would that entail for EU member States and associated countries? This specific context requires further examination and development, which is the purpose of this article. In doing so, this article first provides for a brief background on Palestine/Palestinian refugees within the context of Europe. Secondly, it examines the mandate of UNRWA and its shortcomings. Thirdly, the article analyses four landmark decisions of the Court of Justice of the European Union (CJEU) and summarizes the main findings. Finally, this article predicates the legal implications that a dissolution of UNRWA would have on Palestinians, particularly within the context of the European Union. The article, in its methodological approach, pays great attention to legal analysis and case-law interpretation. It builds upon the existing literature on the subject in order to enhance the legal understanding of the situation of Palestine refugees in Europe and will focus of the consequences in Europe of dismantling UNRWA.

\section{Historical Background}

\subsection{Events in Palestine}

The question of "Palestinian refugees" or "Palestine refugees" is entangled with the history of Palestine. As the origin of the Palestinian question and that of UNRWA are closely linked, it is important to succinctly recall certain events that shaped Palestine and its refugee situation.

Palestine was part of the Ottoman Empire. The first significant political events to mention after the defeat of the Ottomans are i) the British Occupation of Palestine and the British Belfour Declaration in 1917, ii) the adoption of the Palestine Mandate by the League of Nations on 24 July 1922 and iii) the 1923 Treaty of Lausanne that placed Palestine under the British Mandate. ${ }^{9}$ On 29 November 1947, the United Nations General Assembly (UNGA) adopted its Palestine Partition Resolution 181 (II), dividing historic Palestine into a 'Jewish' state and an 'Arab' state. Unlike the first, the latter never came into existence. On 14 May 1948, Britain withdrew from Palestine. At midnight on the same day, the Zionist movement declared the establishment of Israel as a Jewish State on the land of Palestine. As a result, the 1948 War took a place..$^{10}$

Palestinians have experienced several major waves of forced displacement, which are at the origin of the existing predicament of Palestinian refugees. Already during the British Occupation and Mandate on Palestine, thousands of Palestinians, who were abroad, were not able to acquire Palestinian citizenship under the Palestine Citizenship Order of 1925. Others fled during the Palestinian Revolt against the British government, and some were displaced as a result of the British policy of house demolitions. ${ }^{11}$

In 1948, after the UN partition plan of historical Palestine, ${ }^{12}$ and the establishment of Israel and the following war caused the displacement, internally and externally, of 750000 to 900000 Palestinians, comprising up to 66 percent of the Palestinian population at that time. ${ }^{13}$ Palestinians affected by the war and Israeli military hostilities were forced to leave their homes and property and flee to neighbouring Palestinian cities and villages (internal refugees) or neighbouring countries (external refugees), hoping to return after the cessation of hostilities. After the war, Palestinians, who found themselves under the control of the newly established State of Israel, continued to face displacement, as "at least 30000 Palestinians were expelled from Israel, comprising about 15 percent of the total Palestinian population of the State."14 In 1967, Israel occupied the remaining territory of historical Palestine, the Syrian Golan Heights and the Egyptian Sinai Peninsula, ${ }^{15}$ creating another wave of Palestinian refugees. As a direct result of Israeli military hostilities, around 350000 to 400000 Palestinians were displaced, some for the second time. More than one quarter of the population in the West Bank and 70000 Gazans fled to Jordan, Syria, Lebanon, and Egypt. ${ }^{16}$ Since 1967, Israel continues to forcibly displace Palestinian inhabitants of both Israel and

\footnotetext{
9 See Benny Morris, Righteous Victims: A History of the Zionist-Arab Conflict 1881-1999 (New York: Alfred A. Knopf, 1999)

${ }^{10}$ Ibid

${ }^{11}$ Susan Akram and Nidal Al-Azza (eds), Closing Protection Gaps: A Handbook on Protection of Palestinian Refugees in States Signatories to the 1951 Refugee Convention ( $2^{\text {nd }}$ ed., BADIL Resource Center for Palestinian Residency and Refugee Rights, 2015) 7-9

12 The UN General Assembly Resolution 181 (II) of 29 November 1947. It is legally questionable whether the UN in its capacity and under its Charter may decide on the partition of Palestine.

13 The Question of Palestine and the United Nation (New York, the United Nations Department of Public Information, April 2008) 97; see also Akram and Al-Azza (eds), Closing Protection Gaps (n 9).

${ }^{14}$ Also see Akram and Al-Azza (eds), Closing Protection Gaps (n 9) 8.

15 The Six-Day War lasted from June 5 to June 10, 1967; see Benny Morris, Righteous Victims: A History of the Zionist-Arab Conflict 18811999 (New York: Alfred A. Knopf, 1999) 340-343

${ }^{16}$ Ibid
} 
the Occupied Territory through violence and oppression, blockades, military attacks, land expropriation, house demolition, forced disappearance, and imprisonment. ${ }^{17}$

On 28 May 2020, the Israeli Prime Minister Benjamin Netanyahu announced to annex parts of the West Bank in July 2020, based on a conceptual map released by US President Trump's administration. ${ }^{18}$ The July 2020 annexation plan was later pushed back; however, Netanyahu still confirms his willingness to annex certain areas of the West Bank..$^{19}$ Between 5.1 million Palestinians currently live in Palestine, 3.05 million Palestinians in the West Bank and 2.5 Palestinians in the Gaza Strip. ${ }^{20}$

All these events have created and continue to create a Palestinian mass exodus. Less than the half of the World's Palestinian population still lives in historic Palestine. More than 1.5 million people, about one third of the registered Palestine refugees, live in 58 recognized Palestine refugee camps in Jordan, Lebanon, the Syrian Arab Republic, the Gaza Strip and the West Bank, including East Jerusalem. ${ }^{21}$ It must be mentioned that Palestine refugees' legal status differs, depending on the laws and policies of the host country; some Palestine/Palestinian refugees remain stateless. For example, Palestinians in United Arab Emirates and Kuwait have residence status of stateless Palestinians. ${ }^{22}$ In Lebanon, Palestinians remain with no legal citizenship, the only document they hold is a form of identification refugee card or travel document. ${ }^{23}$ While Jordan granted Palestinian refugees the Jordanian citizenship, under Law No 6 of 1954 on Nationality that classifies Jordanian nationals as "any person who, not being Jewish, possessed Palestinian nationality before 15 May 1948 and was a regular resident in [Jordan] between 20 December 1949 and 16 February 1954", 24 many Palestine refugees obtain Jordanian nationality on this basis. However, the citizenship is accompanied with some constrains. ${ }^{25}$ In 1988, and especially over the past few years, "the Jordanian government has been arbitrarily and without notice withdrawing Jordanian nationality from its citizens of Palestinian origin, making them stateless." ${ }^{.26}$ Residents of the West Bank and the Gaza Strip hold a Palestinian nationality granted by the Palestinian Authority in accordance with the Oslo Agreements. ${ }^{27}$

\subsection{The EU's Position towards Palestine}

Some European countries have been actively involved in the division of Palestine and the connected refugee question, mainly France and the UK. These colonial powers, at that time, were at the heart of creating the plight of the indigenous people of Palestine. In 1971, with the Schumann Document, France took the initiative to propose a joint European document to solve the Arab-Israeli conflict, which was unanimously approved by the six member States of the European Economic Community (as it was called at that time) ${ }^{28}$ The document referred to the

\footnotetext{
17 Susan M. Akram and Terry Rempel, 'Temporary Protection as an Instrument for Implementing the Right of Return for Palestinian Refugees' (2004) 22 Boston University International Law Journal 1, 4

${ }^{18}$ See Editorial, 'Explainer: Israel annexation and the West Bank' BBC (22 June 2020) <https://www.bbc.com/news/world-middle-east$52756427>$ accessed on 9 October 2020

19 See Editorial, 'Natanyahu says West Bank annexation pan still on the table' AlJAZEERA (13 August 2020) $<$ https://www.aljazeera.com/news/2020/08/netanyahu-west-bank-annexation-plans-table-200813183431066.html $>$ accessed on 9 October 2020

${ }^{20}$ Palestinian Central Bureau of Statistics, 'About 13.5 Million Palestinians in the Historical Palestine and Diaspora' (11 July 2020) $<$ http://pcbs.gov.ps/post.aspx?lang=en\&ItemID=3774> accessed on 9 October 2020

${ }^{21}$ See UNRWA 'Palestine Refugees' <https://www.unrwa.org/palestine-refugees $>$ accessed on 9 October 2020

${ }^{22}$ See Canada: Immigration and Refugee Board of Canada, Palestine and United Arab Emirates: residence status of stateless Palestinians, including access to employment, education, health care and other services, and the ability to travel in and out of the country; the requirements and procedures to renew residence status; treatment of stateless Palestinians whose residence status has expired (2015-November 2017), 24 November 2017, ZZZ106014.E, available at: https://www.refworld.org/docid/5a8400294.html [accessed 19 January 2021] and Canada: Immigration and Refugee Board of Canada, Kuwait and Palestine: residence status of stateless Palestinians, including access to employment, education, health care and other services, and the ability to travel in and out of the country; the requirements and procedures to renew residence status; treatment of stateless Palestinians whose residency status has expired (2015-November 2017), 24 November 2017, ZZZ106021.E, available at: https://www.refworld.org/docid/5a84030f4.html [accessed 19 January 2021]

${ }^{23}$ Dina Kiwan (2021) Inclusion and citizenship: Syrian and Palestinian refugees in Lebanon, International Journal of Inclusive Education, 25:2, 283-297

${ }^{24}$ Law No. 6 of 1954 on Nationality (last amended 1987) [], 1 January 1954 (Kingdom of Jordan)

${ }^{25}$ See Lex Takkenberg and Francesca Albanese, Palestinian Refugees in International Law, (2 ${ }^{\text {nd }}$ edn, Oxford University Press 2020); Lex Takkenberg, The Status of Palestinian Refugees in International Law ( $1^{\text {st }}$ edn, Clarendon Press 1998) 149-169

26 See Human Rights Watch, "Stateless Again: Palestinian-Origin Jordanians Deprived of their Nationality" 1 February 2010 $<$ https://www.hrw.org/report/2010/02/01/stateless-again/palestinian-origin-jordanians-deprived-their-nationality> accessed 19 January 2021

${ }^{27}$ Israeli-Palestinian Interim Agreement on the West Bank and the Gaza Strip (Oslo II), 28 September 1995. The status of this nationality depends other countries position concerning the recognition of Palestine as state.

${ }^{28}$ Not to be confused with the Schuman Declaration of 1950. See Ilan Greilsammer and Joseph Weiler, 'European political cooperation and the Palestinian-Israeli conflict: an Israeli perspective' in David John Allen and Alfred Pijpers (eds), European Foreign Policy Making and the
} 
UNGA's Resolution 194 (III) and mainly suggested, inter alia, the Israeli withdrawal from the territory occupied in 1967, an international status of Jerusalem, and the right of Palestinian refugees to return to their homes. ${ }^{29}$ The European Community, remarkably, concluded at that time that the "Arab-Israeli war of October 1973 results in an energy crisis and economic problems in Europe." ${ }^{30}$ After the Schumann Document of 1971, the EU has never again explicitly mentioned Palestinian refugees or their right to return in an official document. ${ }^{31}$ In the Venice Declaration of 1980, the nine-member economic committee of the EEC Council declared that "[a] just solution must finally be found to the Palestinian problem, which is not simply one of refugees." ${ }^{32}$ Since then, the EU has been involved in the conflict and developed strategies for cooperation with the different actors in the region, including UNRWA. However, the EU's action is mainly of humanitarian nature (see also 6.).

\section{The United Nations Relief and Work Agency for Palestine Refugees in the Near East (UNRWA)}

\subsection{UNRWA and Its Establishment}

The UN responded to the events that took place since 1948. Following the 1948 War, the UNGA adopted a series of resolutions concerning humanitarian assistance to Palestine refugees, perhaps a gesture to hide the UN involvement and misdeed in the disposition of Palestine. Based on a proposal of the UN Mediator on Palestine, the UNGA adopted Resolution 194 (III) of 11 December 1948, establishing the United Nations Conciliation Commission for Palestine (UNCCP), comprised of the United States, France and Turkey. ${ }^{33}$ Resolution 194 (III) separated the question of Palestine refugees from that of other refugees. The Commission was delegated to assume the "functions given to the United Nations Mediator on Palestine by resolution 186 (S-2)," ${ }^{34}$ assist authorities to find a settlement for Palestine and provide protection and a solution for Palestine refugees, including return, "repatriation, resettlement and economic and social rehabilitation of the refugees and the payment of compensation." ${ }^{35}$ However, since the early 1950s, the UNCCP has not provided Palestine/Palestinian refugees any protection or solution. ${ }^{36}$ The Commission, deprived from resources and nearly dysfunctional, acts as an archive of Palestinian refugee properties documents. ${ }^{37}$

UNRWA was established 8 December 1949 by UNGA Resolution 302 (IV), sponsored by the UK, the USA, France, and Turkey. ${ }^{38}$ UNRWA's establishment came one year after the creation of the UNCCP, in order to complement and support the function of the UNCCP at that time. The UNGA established UNRWA to carry out relief and work programmes for Palestine refugees until a durable solution is provided for Palestine refugees. ${ }^{39}$ However, more than 70 years later, UNRWA still exists and there is still no durable solution for Palestine refugees insight.

UNRWA started operating under its mandate on 1 May 1950. According to Resolution 302 (IV), UNRWA was established to "(a) [...] carry out in collaboration with local governments the direct relief and works programmes as recommended [and] (b) [...] consult with the interested Near Eastern Governments concerning measures to be taken by them preparatory to the time when international assistance for relief and works projects is no longer available." ${ }^{40}$ According to the resolution, two main functions have been assigned to UNRWA: the first function is to provide Palestine refugees with humanitarian assistance and work programmes, whereas the second function concerns preparing concerned governments to take over responsibility when the international assistance ceases to exist.

Arab-Israeli Conflict (The Hague, Nijhoff 1984) 121-160, 133

${ }^{29}$ Alain Gresh, 'The European Union and the Refugee Question' in Naseer Aruri (ed), Palestinian Refugees: The Right of Return, (Pluto Press, 2001) 83. For information on the relationship between the EU and Israel, see Sharon Pardo and Joel Peters, Israel and the European Union: A Documentary History (Lanham, Lexington Books 2013)

${ }^{30}$ The European Union, 'The history of the European Union' (30 April 2020) <https://europa.eu/european-union/about-eu/history_en_> accessed 28 July 2020

${ }^{31}$ Gresh, 'The European Union and the Refugee Question' (n 26) 83

${ }^{32}$ European Council, Venice Declaration on the Middle East (12-13 June 1980) $<$ http://ec.europa.eu/external_relations/mepp/decl/index.htm> accessed 9 October 2020

${ }^{33}$ UNGA Res 194-III (11 December 1948) UN Doc A/RES/194 (III)

${ }^{34}$ Ibid

${ }^{35}$ Ibid

${ }^{36}$ Terry Rempel, 'The United Nations Conciliation Commission for Palestine, Protection, and a Durable Solution for Palestinian Refugees' (Badil- Information and discussion Brief, Issue No. 5, June 2020) 1

${ }^{37}$ Ibid

${ }^{38}$ William Dale, 'UNRWA - A Subsidiary Organ of the United Nations' (1974) 23 International and Comparative Law Quarterly 576, 579

${ }^{39}$ UNGA Res 302- IV (8 December 1949) UN Doc A/RES/302 (IV)

${ }^{40}$ Ibid art 7 
Over the course of seven decades, UNRWA's tasks gradually and substantially grew. In 1950, for example, UNGA Resolution 393 (V) authorized UNRWA to redirect funds into integration. ${ }^{41}$ Resolution 393 (V) states that "the reintegration of the refugees into the economic life of the Near East, either by repatriation or resettlement, is essential in preparation for the time when international assistance is no longer available". ${ }^{2}$ According to UNRWA, "human development and humanitarian services encompass primary and vocational education, primary health care, relief and social services, infrastructure and camp improvement, microfinance and emergency response, including in situations of armed conflict." ${ }^{, 3}$ UNRWA has also identified four main human development goals for Palestine refugees, which comprise of 1) acquiring knowledge and skills (education), 2) leading healthy lives, 3) achieving decent standards of living, and 4) enjoying human rights.

UNRWA was established at a time when the UNCCP was still in operation, and it was the latter that was supposed to protect Palestine refugees. Therefore, UNRWA was not given a mandate to protect. Furthermore, UNGA resolutions, including those that created the UNCCP and UNRWA, do not provide for a full protection for Palestine refugees, creating a protection gap under international law (see infra, 3.2.). UNRWA is a subsidiary organ of the UN, directly under the General Assembly, created under Articles 7(2) and 22 of the UN Charter. The mandate of UNRWA is temporary, pending until a just solution is found for the Palestine refugees' plight. Thus, UNRWA has a special mandate, that, unlike some other $\mathrm{UN}$ agencies who have statutes, is derived from and laid down in different UNGA resolutions. ${ }^{44}$ UNRWA is not independent from the political entity of the United Nations, the UNGA regularly decides on the existence of UNRWA. Since its establishment, UNRWA's mandate is periodically renewed by the UNGA, often every three years. The latest renewal was voted upon on 13 December 2019; UNRWA's mandate is now valid until $2023 .{ }^{45}$ UNRWA is mostly funded by voluntary contributions from UN member States. It also receives some funding from the regular budget of the United Nations. ${ }^{46}$ UNRWA depends, almost entirely, on voluntary these contributions to provide for services in five areas, namely the West Bank, including East Jerusalem, the Gaza Strip, Jordan, Lebanon, and Syria. These different geographical areas imply different legal, political and economic contexts.

The beneficiaries of UNRWA's services are defined strictly. UNRWA's definition initially focused on those refugees who lost their home and work in Palestine and fled as a result of the 1948 war. UNRWA defines Palestine refugees as "persons whose normal place of residence was Palestine during the period 1 June 1946 to 15 May 1948, and who lost both home and means of livelihood as a result of the 1948 conflict." ${ }^{\prime \prime 7}$ Its service is available only to those who meet this definition, live in UNRWA's designated areas of operations, are registered with the Agency and need assistance. The Agency determines who is eligible under its definition, and proceeds with the registration of the beneficiaries.

On 4 July 1967, following the 1967 war, the UNGA adopted Resolution 2252 (ES-V), endorsing UNRWA's urgent assistance "as a temporary measure, to other persons in the area who are at present displaced and are in serious need of immediate assistance as a result of the recent hostilities." ${ }^{48}$ Thus, those who have been displaced in 1967 are also included in UNRWA's mandate. UNRWA first exclusively included the "descendants of Palestine refugee males, including legally adopted children." ${ }^{49}$ This exclusion, as a form of gender discrimination, was criticized. However, in 2006, UNRWA declared that family members, husbands and descendants of registered refugee women, married to non-refugees, are also eligible to be registered to receive UNRWA services. ${ }^{50}$

\subsection{The Establishment of UNRWA's Protection Division (2016)}

Scholars have directed critiques against UNRWA; the main critique emphasizes the existence of a protection gap, ${ }^{51}$ which leaves Palestine refugees with less protection and rights than those granted to other refugees under the

\footnotetext{
${ }^{41}$ See UNGA Res 393-V (2 December 1950) UN Doc A/RES/393(V); UNGA Res 513-VI (6 January 1952) UN Doc. A/RES/513(VI); UNGA Res 2252 (ES-V); UNGA Res 2535 (XXIV), UNGA Res 2792 (XXVI), and UNGA Res 2963 (XXVII)

42 UNGA Res 393-V (2 December 1950) UN Doc A/RES/393 (V)

${ }^{43}$ UNRWA, 'What we do' $<$ https://www.unrwa.org/what-we-do $>$ accessed 9 October 2020

${ }^{44}$ Lance Bartholomeusz, 'The Mandate of UNRWA at Sixty' (2009) 28 Refugee Survey Quarterly, 452, 453-454

${ }^{45}$ UNGA 'Special Political and Decolonization Committee- Fourth Committee' UNRWA 74 ${ }^{\text {th }}$ Session UN Doc. A/C.4/74/L.10 (11 November 2019)

${ }^{46}$ See UNRWA, 'Who we are' <https://www.unrwa.org/who-we-are> accessed 20 July 2020

47 UNRWA (n 21)

48 UNGA Res 2252 (ES-V) (4 July 1967) UN Doc A/RES/2252 (ES-V)

49 UNRWA (n 21)

${ }^{50}$ UNRWA, 'Eligibility Registration'<https://www.unrwa.org/what-we-do/eligibility-registration> accessed 9 October 2020

${ }^{51}$ See Section 3.3
} 
instruments of the international (refugee law) regime, namely the Refugee Convention of 1951, its 1967 Protocol, and the 1954 Convention of Stateless Persons. ${ }^{52}$ UNRWA does not have a political or legal protection mandate, neither is it meant to find a solution for the Palestinian problem, but merely to provide for humanitarian assistance to Palestine refugees that fall under its scope. However, over time, as stated earlier, the mandate of UNRWA has developed. Efforts to strengthen its protection response have increased in order to respond to the evolving challenges. UNRWA indicates that, since 2015, there are protection teams working in its five operating areas. ${ }^{53}$

In January 2016, a new Protection Division was established to "provide strategic direction of, and coordination to, the implementation of the diverse protection activities across the Agency [..., including] providing technical support to the protection teams [...] and supporting the key role of programme by providing protection in and through UNRWA's service delivery... [it also integrates] thematic strands of protection work [, including] child protection, gender/gender-based violence (GBV), and disability." ${ }^{54}$ The protection mandate of UNRWA, including its Protection Division, aims at ensuring that Palestine refugees' rights are protected and promoted under international law. This protection is reflected in UNRWA's Strategic Outcome 1 of the Medium-Term Strategy 2016-2021. ${ }^{55}$ According to several UNGA resolutions, the protection focuses on "addressing the needs, rights and protection of children, women and persons with disabilities in its operations, including through the provision of necessary psychosocial and humanitarian support, in accordance with the Convention on the Rights of the Child, the Convention on the Elimination of All Forms of Discrimination against Women and the Convention on the Rights of Persons with Disabilities." ${ } 56$

In practice, the Protection Division was not able to offer additional protection, in terms of legal protection and enforcement mechanisms. UNRWA still does not provide sufficient legal protection. Although tasks such as education and health care are being performed by UNRWA, it does of course not offer the same level of protection that a State would offer to its nationals or residents in terms of security, access to legal remedies, the rule of law, political representation, etc. The Protection Division of UNRWA does not provide more than "strategic direction of, and coordination to, the implementation of the diverse protection activities across the Agency, including child protection, gender and GBV, disability and mental health and psychosocial support (MHPSS)." ${ }^{7}$ This development, therefore, does not address the identified protection gap (see 3.3) or provide for a better protection of human rights.

\subsection{The Protection Gap}

The 1951 Refugee Convention outlines a set of important fundamental aspects to protect the rights of refugees. It seeks to protect some basic human rights which should be at least equivalent to freedoms enjoyed by foreign nationals living legally in a given country, such basic rights include freedom of religion and movement, the right to work, education and accessibility to travel documents. ${ }^{58}$ The Convention and its protocol also introduce the principle of non-refoulement, which provides that states must not return refugees to a place where their life and freedoms are at risk. The 1954 Stateless Persons similarly ensures that stateless persons have a minimum set of human rights. ${ }^{59}$ The European Union's Qualification Directive of 2011 also ensures the respect of fundamental rights and seeks to protect, inter alia, human dignity, equality, the right to seek asylum and the right to work. ${ }^{60}$ In

\footnotetext{
52 See Susan M Akram, 'Palestinian Refugees and Their Legal Status: Rights, Politics, and Implications for a Just Solution' (2002) 31 Journal of Palestine Studies 36; Susan M Akram and Terry Rempel, 'Temporary Protection as an Instrument for Implementing the Right of Return for Palestinian Refugees' (2004) 22 Boston University International Law Journal 1; Susan M Akram, 'UNRWA and Palestinian Refugees' in Elena Fiddian-Qasmiyeh and others (eds), The Oxford Handbook of Refugee and Forced Migration Studies (Oxford University Press 2014); Neil Gambian, 'Negotiating Rights: Palestinian Refugees and the Protection Gap' (2006) 79 Anthropological Quarterly 717; Asem Khalil, 'Palestinian Refugees in Arab States: A Rights-Based Approach' (2009) Robert Schuman Centre for Advanced Studies, European University Institute, CARIM Research Reports 2009/08; Are Knudsen, "Widening the Protection Gap: The "Politics of Citizenship" for Palestinian Refugees in Lebanon, 1948-2008' (2009) 22 Journal of Refugee Studies 51; Noura Erakat, 'Palestinian Refugees and the Syrian Uprising: Filling the Protection Gap during Secondary Forced Displacement' (2014) 26 International Journal of Refugee Law 581; Susan Akram and Nidal Al-Azza (eds), Closing Protection Gaps: A Handbook on Protection of Palestinian Refugees in States Signatories to the 1951 Refugee Convention ( $2^{\text {nd }}$ ed., BADIL Resource Center for Palestinian Residency and Refugee Rights, 2015)

${ }^{53}$ UNRWA, 'Protection Division' < https://www.unrwa.org/protection-division> accessed 2 August 2020

${ }^{54} \mathrm{Ibid}$

${ }^{55}$ UNRWA, 'Medium-Term Strategy 2016-2021' (UNRWA 2016) 30

${ }^{56}$ UNGA Res 72/82 (7 December 2017) UN Doc A/RES/72/82, para 25; UNGA Res 71/93 (6 December 2016) UN Doc A/RES/71/93, para 18; UNGA 70/85 (9 December 2015) UN Doc A/RES/70/85, para 17

${ }^{57}$ UNRWA, 'What do we do: protection' $<$ https://www.unrwa.org/what-we-do/protection $\geq$ accessed 9 August 2020

${ }^{58}$ Convention Relating to the Status of Refugees of 1951, arts 4, 5, 12, 21, 22, 24, 26, 27, and 28.

59 Convention Relating to the Status of Stateless Persons of 1954, arts 3, 4, 12, 13, 15, 16, 17, 21, 22, and 24.

${ }^{60}$ DIRECTIVE 2011/95/EU OF THE EUROPEAN PARLIAMENT AND OF THE COUNCIL of 13 December 2011 on standards for the
} 
addition to the basic rights provided under the Conventions of 1951 and 1954 as well as the EU Qualification Directive, the international refugee regime provides for mechanisms to safeguard such a protection.

The Conventions and their companion agencies and instruments set up a special regime for Palestine refugees through an exclusion provision. Article 1D of the 1951 Refugee Convention states that:

"This Convention shall not apply to persons who are at present receiving from organs or agencies of the United Nations other than the United Nations High Commissioner for Refugees protection or assistance.

When such protection or assistance has ceased for any reason, without the position of such persons being definitively settled in accordance with the relevant resolutions adopted by the General Assembly of the United Nations, these persons shall ipso facto be entitled to the benefits of this Convention." $" 61$

The clause is constructed as one of the exclusion grounds from the refugee definition. Article 1(2)(i) of the Convention relating to the Status of Stateless Persons of 1954 and Article 12(1)(a) of the EU Qualification Directive of 2011 contain the same exclusion clauses. The only agency of the United Nations (other than the United Nations High Commissioner for Refugees) that currently offers assistance to a certain group of persons is UNRWA. Thus, Palestinians refugees are excluded from the international refugee protection regime and exclusively benefit from the UNRWA mandate that provides only relief and work programmes. Basic human rights and freedoms are not mentioned or included within UNRWA's mandate.

In the light of the exclusion of these three stated instruments, several scholars argue that Article 1D of the Refugee Convention of 1951 singles out Palestine refugees and excludes them from the protection of the Refugee Convention, Article 1D therefore creates a protection gap. ${ }^{62}$ Other scholars, however, emphasize that, in addition to the protection by UNRWA, Palestinian refugees benefit from other international human rights and humanitarian law instruments. ${ }^{63}$ Therefore, including Palestine refugees in the Refugee Convention and placing them under the mandate of the Office of the UN High Commissioner for Refugees (UNHCR) would not have placed Palestinian refugees in a better situation. ${ }^{64}$ The latter argument seemingly does not consider the principle of equality enriched in the international refugee law regime. The crucial issue that stands is leaving Palestinians disadvantaged, compared to other refugees, because of such exclusion clause.

Article 1D (2) of the Refugee Convention adds that "(w)hen such protection or assistance has ceased for any reason, without the position of such persons being definitively settled in accordance with the relevant resolutions adopted by the General Assembly of the United Nations, these persons shall ipso facto be entitled to the benefits of this Convention." Should UNRWA cease to exist, Palestinian refugees would automatically be entitled to full protection. Article 1D of the Refugee Convention therefore not only contains an exclusion ground, but also an inclusion ground in case of dismantling UNRWA.

It is not clear how this special inclusion ground would have to be handled in practice. It could be logic that Palestinian refugees that fall under the ipso facto protection clause do not have to prove fulfilling the refugee definition of Article 1 (A) (2) of the Refugee Convention. However, it is open whether the ipso facto protection would automatically make them refugees, or whether they are "just" included under the scope of the convention and therefore entitled to the same rights as refugees. The absence of an international court interpreting the Refugee Convention leaves it up to the signatory States to handle this. The differences in practice of the two possible interpretations seem neglectable. However, many questions around the interpretation of Article 1D of the Refugee Convention still remain unanswered. This is why the case-law of the Court of Justice of the European Union (CJEU) is significant, as it could influence the interpretation of the provision also on an international level and therefore set the international standard. ${ }^{65}$

What is undoubtable is that a durable solution to the Palestine refugee problem is still not insight. According to

qualification of third-country nationals or stateless persons as beneficiaries of international protection, for a uniform status for refugees or for persons eligible for subsidiary protection, and for the content of the protection granted. Official Journal of the European Union L337/9.

${ }^{61}$ Convention Relating to the Status of Refugees of 195, art 1D

${ }^{62}$ Susan M Akram, 'Palestinian Refugees and Their Legal Status: Rights, Politics, and Implications for a Just Solution' (2002) 31 Journal of Palestine Studies 36, 36-51

${ }^{63}$ Damian Lilly, 'UNRWA's Protection Mandate: Closing the Protection Gap' (2018) 30 International Journal of Refugee Law 444

${ }^{64}$ Ibid

${ }^{65}$ See section 4 
UNHCR, such a durable solution would consist of voluntary repatriation, local integration or resettlement. ${ }^{66}$ UNHCR also recognizes that voluntary repatriation in conditions of safety and dignity remains the preferred solution for refugees. ${ }^{67}$ A durable solution for Palestinian refugees must follow the same approach. The UNGA recent Resolution no. A/C.4/74/L.13 affirms the importance of Palestine refugees' right to their properties and to the revenues derived therefrom. ${ }^{68}$ However, remedies, reparation, and a durable solution do not seem to be a goal of the International Community ${ }^{69}$ and is not included within the UNRWA's mandate. The absence of a coherent international policy with regard to Palestinian refugees and the failure of the international community to effectively protect Palestinians are strong indicators that the protection gap exists. So far, UNRWA has not been able to remedy this. It is, therefore, desirable and necessary to include Palestine refugees under the UNHCR mandate, create a new legal framework for Palestine refugees or enlarge UNRWA's mandate to fully grant Palestinians the human rights protection that they are entitled to under international law.

\section{The Protection of Palestinian Refugees in EU Law: An Analysis of the Case-Law of the CJEU}

The question of Palestine/Palestinian refugees within the European Union context is indirectly determined in the exclusion article of the Qualification Directive. Article 12 (1) (a) of the Qualification Directive ${ }^{70}$ transposes $^{2}$ Article $1 \mathrm{D}$ of the Geneva Convention in that, it states that

"a third-country national or a stateless person is excluded from being a refugee if he or she falls within the scope of Article $1 \mathrm{D}$ of the Geneva Convention, relating to protection or assistance from organs or agencies of the United Nations other than the United Nations High Commissioner for Refugees. When such protection or assistance has ceased for any reason, without the position of such persons being definitely settled in accordance with the relevant resolutions adopted by the General Assembly of the United Nations, those persons shall ipso facto be entitled to the benefits of this Directive". ${ }^{71}$

Via the integration of the terms of the Refugee Convention into the Qualification Directive, the Court of Justice of the European Union received the competence to interpret these clauses. It does of course not directly interpret the Convention, but only the Qualification Directive. The Court still interprets the same notions and is, thus, likely to set - or at least influence - the international standard when it comes to their definition and scope. In other words, the interpretation of the CJEU could be adopted by international entities, UN relevant bodies, in light of how Palestine/Palestinian refugees are treated. On the one hand, the EU member States, including their judiciary and migration policies, should, in principle, follow the interpretations of the CJEU. This, in turn, could lead to a state practice at the international level - at minimum expectations - that would be at the European level. On the other hand, since the exclusion provision in the EU Directive mirrors the international exclusion provisions, the interpretation of these provisions is likely to be similar and interactive. The way the CJEU has understood the EU exclusion provision would most likely influence the way the international community understands the international exclusion provisions, and vice versa.

An important aspect to note is that, compared to the Geneva Convention, the Qualification Directive has a limited personal scope. It is only applicable to "third-country nationals or stateless persons" (Article 2 (d) and (e) of the Directive). Who is a third-country national has to be determined from an EU perspective? Third-country nationals are simply citizens of non-EU States. The Geneva Convention does not contain such a limitation, meaning that it is, unquestionably, applicable to citizens of EU member States. However, this aspect is of no importance in the context of Palestine refugees, as Palestinians are third-country nationals.

Article 12 (1) (a) of the Qualification Directive gives rise to the following questions:

- Under which circumstances do Palestinians fall under the exclusion clause of Article 12 (1) (a) of the Qualification Directive?

${ }^{66}$ Executive Committee of the High Commissioner's Programme, Conclusion on International Protection No. 90 (LII) - 2001 (5 October 2001) No. 90 (LII), para (j) <https://www.refworld.org/docid/3bd3e3024.html> accessed 9 July 2020

${ }^{67}$ Ibid

${ }^{68}$ UNGA Res 74/L.13 (11 November 2019) UN Doc A/C.4/74/L.13

${ }^{69}$ Akram and Rempel, 'Temporary Protection' (n 17)

${ }^{70}$ Directive 2011/95/EU of the European Parliament and of the Council of 13 December 2011 on standards for the qualification of thirdcountry nationals or stateless persons as beneficiaries of international protection, for a uniform status for refugees or for persons eligible for subsidiary protection, and for the content of the protection granted, OJ L 337, 20.12.2011, p. 9-26. See also the first phase directive: Council Directive 2004/83/EC of 29 April 2004 on minimum standards for the qualification and status of third country nationals or stateless persons as refugees or as persons who otherwise need international protection and the content of the protection granted, OJ L 304, 30.9.2004, p. 12-23. However, in the 2011 version of the directive, Article 12 (1) (a) remained unchanged.

${ }^{71}$ Ibid, art 12(1)(a). 
- When has the protection or assistance of UNRWA ceased? What does "ceased for any reason" mean?

- If UNRWA or its assistance ceases to exist, what happens to Palestinian refugees? Will they (automatically) be considered as refugees? What means being "ipso facto" entitled to the benefits of the Directive?

- Do Palestinians have to deposit an application for refugee status or do authorities have to examine Article 12 (1) (a) of the Qualification Directive ex officio?

- Does Article 12 (1) (a) of the Qualification Directive have direct effect?

- What law applies to stateless Palestinians?

These questions have been answered by the CJUE in four landmark judgments. These judgements are presented in this section.

\subsection{The Bolbol Case}

The first time that the Court of Justice of the European Union (CJEU) had to interpret the exclusion clause of Article 12 (1) (a) of the Qualification Directive was in 2010, on the occasion of the Bolbol case. ${ }^{72}$ In 2007, Ms. Bolbol, a Palestinian, entered Hungary with a visa, coming from the Gaza Strip. She obtained a residence permit from the Hungarian immigration authority. In June 2007, she submitted an application for asylum to the Hungarian immigration authority, invoking the unsafe situation in the Gaza Strip caused by the daily clashes between Fatah and Hamas. Ms. Bolbol based her application on the second subparagraph of Article 1D of the Geneva Convention, pointing out that she was a Palestinian residing outside UNRWA's area of operations. It was undisputed that Ms. Bolbol had never availed herself of the protection or assistance of UNRWA. She claimed, however, to be entitled to such protection and assistance, relying in support of that claim on an UNRWA registration card issued to the family of her father's cousins.

The authority rejected her application, since Ms. Bolbol did not leave her country of origin owing to persecution for reasons of race, religion, nationality or because of political persecution. Ms. Bolbol challenged this decision, pointing out that, as a displaced Palestinian, she was entitled to the special protection provided for in Article 1D of the Geneva Convention, referred to by Article 12 (1) (a) of the Qualification Directive. The Budapest Municipal Court decided to stay the proceeding and refer three questions to the Court for a preliminary ruling, each of them concerning the interpretation of Article 12 (1) (a) of the Qualification Directive. In its judgment, the CJEU only answered the question whether a person receives protection and assistance from UNRWA by virtue of the mere fact that he or she is entitled to that protection or assistance, or whether that person must have actually availed himself or herself of that protection or assistance.

First, the Court made it clear that it cannot be maintained that only those Palestinians who became refugees as a result of the 1948 conflict, who were receiving protection or assistance from UNRWA at the time when the original version of the Geneva Convention was concluded in 1951, are covered by Article 1D of that convention. ${ }^{73}$ Therefore, also persons displaced following the 1967 hostilities are covered by Article 12(1)(a) of the Directive. The Court, secondly, elaborated that it follows from the clear wording of Article 1D of the Geneva Convention that only those persons who have actually availed themselves of the assistance provided by UNRWA come within the clause excluding refugee status set out therein. The clause must, as such, be interpreted narrowly and therefore cannot also cover persons who are or have been eligible to receive protection or assistance from that agency.

As Ms. Bolbol had not availed herself of protection or assistance from UNRWA, she could not be considered to fall under Article 12 (1) (a) of the Qualification Directive. However, as the Court added, persons who have not actually availed themselves of protection or assistance from UNRWA, may, in any event, have their application examined in order to find out whether they fulfil the refugee definition. The Court ruled that two points were unnecessary to address. The first concerns the circumstances under which assistance from UNRWA may have ceased for any reason, and second concerns the nature of the benefits convened by the directive under which the person concerned may be entitled to ipso facto as a result of the cessation of the UNRWA assistance ${ }^{74}$

\subsection{The El Kott Case}

The second case decided by the CJEU was the El Kott case in 2012. ${ }^{75}$ Mr Abed El Karem El Kott lived in difficult circumstances at the Ein El-Hilweh refugee camp in Lebanon, which under the operational mandate of UNRWA.

\footnotetext{
72 CJUE, case C-31/09, Bolbol, ECLI:EU:C:2010:351. The case was decided on the basis of the 2004 Qualification Directive.

${ }^{73}$ Ibid (n47), this was argued by the United Kingdom.

${ }^{74}$ Ibid, para 52-53

${ }^{75}$ CJEU, case C-364/11, El Kott, ECLI:EU:C:2012:826
} 
Under these circumstances, $\mathrm{Mr}$ El Kott left the camp after he was threatened, and his house was burned down. $\mathrm{Mr}$ Kamel Ismail also lived with his family in the Ein El-Hilweh camp in Lebanon. Mr Ismail stated that "during armed clashes between Fatah and the Jund el-Sham, extremists wanted to use the roof of his house. When he refused, he was threatened with death and suspected as an 'enemy agent'. Unable to protect himself, he left with his family for Beirut. As he did not feel safe there, he fled to Hungary. He produced a certificate from the Palestinian People's Committee to the effect that he and his family had had to leave the Ein El-Hilweh camp for safety reasons and because of radical Islamist threats, together with photographs of their house after it had been vandalized." $" 76$

Mr. A Radi's home, in the Nahr el Bared UNRWA refugee camp in Lebanon, "was destroyed in May 2007 as the result of clashes between the Lebanese army and Islamic Fatah.... no space to accommodate him in the [nearby] Baddawi camp, Mr A Radi, together with his parents and siblings, stayed with an acquaintance in Tripoli, Lebanon... Lebanese soldiers insulted and mistreated them, arrested them arbitrarily, tortured and humiliated them ... as Palestinians, they had no rights in Lebanon, Mr. A Radi left that country with his father."”7

Mr. El Kott, Mr. Radi and Mr. Ismail applied for asylum in Hungary. The Hungarian Office for Immigration and Citizenship refused to grant them refugee status. The authority did not recognize Mr. El Kott and Mr. Radi as refugees but ordered that they should not be returned. Mr. Ismail received subsidiary protection. All three men lodged appeals against the refusal to recognize them as refugees. The applicants submitted that, in their case, since UNRWA protection had ceased, they were automatically entitled to recognition of their legal status as refugees.

In its judgment, the CJUE stated that "it is not only the abolition itself of the organ or agency giving protection or assistance which brings about the cessation of the protection or assistance provided by that organ or agency within the meaning of the second sentence of Article 12(1)(a) of the Qualification Directive but also the fact that it is impossible for that organ or agency to carry out its mission." 78 The Court further argues that it is apparent from the words '[w]hen such protection or assistance has ceased', which introduces the second sentence of Article 12(1) (a), that it is primarily the actual assistance provided by UNRWA and not the existence of that agency itself which must cease in order for the ground for exclusion from refugee status no longer to be applicable.

According to the CJUE, 'the use of the words 'for any reason' which follow in that second sentence indicates that that provision is to be interpreted as meaning that the reason for which assistance has ceased may also be attributable to circumstances which have forced the person concerned to leave the UNRWA area of operations as they are beyond that person's control." ${ }^{\prime 79}$ Mere absence from such an area or a voluntary decision to leave it cannot be regarded as cessation of assistance. On the other hand, if the person concerned has been forced to leave for reasons isolated from that person's will, such a situation may lead to a finding that the assistance from which that person benefited has ceased within the meaning of the second sentence of Article 12(1)(a) of the Qualification Directive. $^{80}$

It is under the discretion of the competent national authorities and courts to ascertain whether the departure of the person concerned may be justified by reasons beyond his or her control and independent of his or her volition which forced him or her to leave the area in question and thus prevented him or her from receiving UNRWA assistance. A Palestinian refugee must be regarded as having been forced to leave UNRWA's area of operations if his or her personal safety is at serious risk and if it is impossible for UNRWA to guarantee that his or her living conditions in that area will be commensurate with the mission entrusted to UNRWA.

The competent national authorities - those responsible for examining the asylum application - of the member States must carry out an assessment, on an individual basis, of all the relevant factors. Article 4(3) of Qualification Directive is applicable by analogy. Where the competent authorities have established that the condition relating to the cessation of UNRWA protection or assistance is satisfied as regards the applicant, ipso facto applies. The fact that that person is ipso facto 'entitled to the benefits of [the] directive' means that that member State must recognize him or her as a refugee within the meaning of Article 2(c) of the Directive and that person must automatically be granted refugee status, provided always that he or she is not caught by Article 12(1)(b) or (2) and (3) of the Directive. ${ }^{81}$

\footnotetext{
${ }^{76}$ Ibid, para 32

${ }^{77}$ Ibid, para 30

${ }^{78}$ Ibid, para 56

${ }^{79}$ Ibid, para 58

${ }^{80}$ Ibid

${ }^{81}$ Ibid
} 
However, the CJEU emphasized that Palestinians must submit applications for refugee status, which must then be examined by the competent authorities of the member State responsible. In carrying out that examination, those authorities must verify not only that the applicants actually sought assistance from UNRWA and that the assistance has ceased, but also that the applicants are not caught by other exclusion grounds laid down in Article 12(1)(b) or (2) and (3) of the directive. However, it is not necessarily required to show that a Palestinian has a well-founded fear of being persecuted within the meaning of Article 2(c) of the directive.

\subsection{The Alheto Case}

The third time that the CJEU had to deal with Article 12 (1) (a) of the Qualification Directive was in 2018, in the Alheto judgment. ${ }^{82}$ Ms. Alheto holds a passport issued by the Palestinian National Authority and is registered with UNRWA. In July 2014, Ms. Alheto left the Gaza Strip via underground tunnels linking that territory to Egypt, and from there she went on to Jordan by boat. ${ }^{83}$ In August 2014, the consular service of the Republic of Bulgaria in Jordan issued Ms. Alheto with a tourist visa for travel to Bulgaria. ${ }^{84}$ A few days later, Ms Alheto entered Bulgaria, where she lodged an application for international protection. Ms. Alheto argued that to return to the Gaza Strip would expose her to a serious threat to her life, since she would risk experiencing torture and persecution there. Her application was refused.

In the Alheto judgment, the CJEU recalled that the examination of an application for international protection, the concerned authority must determine whether the applicant qualifies as a refugee. Hence, the fact that the provisions of Article 12(1)(a) of the Qualification Directive do not apply to the part of the application relating to subsidiary protection does not exempt the competent authority from its obligation. This obligation is to primarily apply the rules transposing these provisions in order to verify whether refugee status must be granted. The Court then elaborated that Article 12 (1) (a) precludes national legislation which does not lay down or which incorrectly transposes the ground for no longer applying the ground for exclusion from being a refugee contained therein, that Article 12 (1) (a) has direct effect and that it is applicable even if the applicant for international protection has not expressly referred to it.

The remaining questions concerned procedural aspects.

\subsection{The XT Case}

In its last judgment dealing with Palestinian asylum seekers, on the occasion of the XT case, the CJEU had to answer questions about the interpretation of Article 12 (1) (a) to the special situation of stateless Palestinians. ${ }^{85}$ The case concerned XT, a stateless person of Palestinian origin, who was born and raised in Syria, where she was registered with UNRWA in the camp of Yarmouk. XT temporarily resided in Lebanon and then returned to Syria, before finally leaving for Germany, where he was granted subsidiary protection. On appeal, the Higher Administrative Court granted him refugee status, concluding that he was at a serious risk in Syria.

The CJEU held that in order to assess whether the protection of UNRWA has ceased, it is necessary to consider all the fields of UNRWA's area of operations which a stateless person who has left that area has a concrete possibility of accessing and safely remaining therein. UNRWA's protection cannot be regarded as having ceased where a stateless person of Palestinian origin has left the UNRWA area of operations from a field in that area in which his or her personal safety was at serious risk and in which UNRWA was not in a position to provide that individual with protection or assistance, if that person voluntarily travelled to that field from another field of operations where his or her personal safety was not at risk and in which he or she could obtain protection from UNRWA, and if that person could not reasonably expect to receive protection from UNRWA in the field to which he or she travelled.

Therefore, the departure from one of UNRWA's fields of operations is not involuntary, if the person was able to access another field of operations of UNRWA in order to receive protection or assistance. The national court therefore had to verify whether XT was able to get protection by UNRWA in Lebanon and voluntarily departed from that field of operations to the one in Syria.

\subsection{Summary of the CJEU Case-Law on Article 12 (1) (a) of the Qualification Directive}

The above-mentioned judgments amount to the following four basic principles regarding applications for international protection lodged by Palestinians:

\footnotetext{
${ }^{82}$ CJEU, case C-585/16, Alheto, ECLI : EU:C:2018:584

${ }^{83}$ Ibid

${ }^{84} \mathrm{Ibid}$

${ }^{85}$ CJEU, case C-507/19, XT, ECLI:EU:C:2021:3.
} 
1) Even if a Palestinian does not explicitly ask for an assessment under Article 12 (1) (a) of the Qualification Directive, it must first be assessed whether the applicant must be granted refugee status, before analysing a claim for subsidiary protection. However, the Palestinian must necessarily deposit an application.

2) In order to fall under Article 12 (1) (a) of the Qualification Directive, a Palestinian must have actually availed himself or herself of the assistance provided by UNRWA.

3) The assistance of UNRWA is considered to have ceased in the following cases: (a) if UNRWA no longer exists and (b) the Palestinian has been forced to leave the area of UNRWA operations for reasons unconnected with his or her will; this is the case when his or her personal safety is at serious risk and if it is impossible for UNRWA to guarantee that the living conditions in the area under UNRWA mandate will be commensurate with the mission entrusted to UNRWA. Mere absence from the area of UNRWA operations or a voluntary decision to leave it cannot be regarded as cessation of assistance.

4) If it is established that the assistance of UNRWA has ceased, the Palestinian must automatically be granted refugee status, provided that he or she is not caught by another exclusion ground (Articles 12(1)(b) or (2) and (3) of the Qualification Directive). The Palestinian does not need to show that he or she has a well-founded fear of being persecuted.

5) If a person is stateless and travels from one area of protection of UNRWA to another, it has to be assessed whether protection was available in the first area. If it was not, the departure from UNRWA's area of operations as a whole cannot be considered voluntary.

In conclusion, the cases presented above have made it clear that if UNRWA stops to exist or is unable to guarantee decent living conditions in its area of operations, Palestinian refugees will be entitled to refugee status in the EU member States without having to demonstrate individual persecution (ipso facto protection), provided of course that they do not fulfil other exclusion grounds and that they do not come from a country of first asylum or a safe third country that is willing to take them back. The legal implications of an abrogation of UNRWA, particularly within the EU context, are described in the following section.

\section{UNRWA and Current Challenges: EU Support and Possible Abrogation of UNRWA}

Throughout its more than 70 years of operation, UNRWA has annually reported mainly political and financial, but also social obstacles and challenges to the implementation of its mandate. ${ }^{86}$ These challenges are also apparent in the language of different UNGA resolutions, ${ }^{87}$ especially those renewing UNRWA's mandate ${ }^{88}$ The temporary mandate and total reliance on voluntary contributions situate UNRWA in a very fragile and unsustainable situation. The Officer-in-Charge of UNRWA, Mr. Christian Saunders, in November 2019, addressed the Special Political and Decolonization Committee of the UNGA, focusing on political and financial challenges, stating that UNRWA "is undergoing the worst financial crisis in its history" 89

This financial predicament is the result of an abrupt end to funding by the United States in $2018 .^{90}$ The US claimed that the decision to cut funding was taken due to UNRWA's financial mismanagement, procedural irregularities and the illegality of its definition of entitled beneficiaries. ${ }^{91}$ However, it seems likely that the US policy towards UNRWA has aimed at dismantling it through defunding. The decision not to fund UNRWA anymore has been used as a political tool to pressure the Palestinian Authority to succumb under the US peace plan. The end of US funding has forced UNRWA to pledge for additional support from other countries, including the European Union. At the $73^{\text {rd }}$ session, $24^{\text {th }}$ meeting of the Fourth Committee (Special Political and Decolonization), on 9 November 2018, the EU delegation warned that "ending UNRWA's humanitarian activities could generate instability across the region and create a vacuum that will only serve extremists... [The EU] and its member States are collectively the largest contributor to UNRWA's budget and among the first to respond to its call for additional funds...

\footnotetext{
${ }^{86}$ See UNRWA's annual operational reports

${ }^{87}$ UNGA 'Special Political and Decolonization Committee- Fourth Committee' (n 39)

${ }^{88}$ Ibid

${ }^{89}$ UNRWA, 'UNRWA appeals financial and political support at the General Assembly's Fourth Committee- Press Release (13 November 2019) <https://www.unrwa.org/newsroom/press-releases/unrwa-appeals-financial-and-political-support-general-assembly $\%$ E2\% $80 \% 99$ sfourth $>$ accessed 10 August 2020

${ }^{90} \mathrm{UN}$ 'UNRWA Faces Greatest Financial Crisis in its History Following 2018 funding Cuts, Commissioner-General Tells Fourth CommitteePress Release' (9 November 2019) <https://www.un.org/unispal/document/unrwa-faces-greatest-financial-crisis-in-its-history-following2018-funding-cuts-commissioner\%E2\%80\%91 general-tells-fourth-committee-press-release/> accessed 12 July 2020

${ }^{91}$ Heather Nauert, 'On U.S. Assistance to UNRWA, Press Statement' (31 August 2018) <https://www.state.gov/on-u-s-assistance-to-unrwa/> accessed 6 July 2020; for more analysis on the issue, see Francesca Albanese, 'UNRWA and Palestine Refugee Rights: New Assaults, New Challenges' (2018) Institute for Palestine Studies, 11
} 
acknowledging the far-reaching reforms undertaken by UNRWA to counter the shortfall and contain its impact... [calling] upon donors to intensify their efforts to help the Agency find its financial footing while staying focused on its mandate." 92

The EU developed strategies for cooperation with the different actors in the region, including UNRWA, and published a multi-annual action programme to support UNRWA..$^{93}$ The EU considers its support to UNRWA, in general and under its European Neighbourhood Policy, as an "essential element of the EU's strategy to bring peace, stability and prosperity to the region and represents the EU's longstanding commitment to Palestine refugees until a just resolution to their plight is accomplished." ${ }^{\text {"94 }}$ Notably, in 2017, the EU and UNRWA signed a 2017-2020 Joint Declaration in order to strengthen their political partnership, where the EU reaffirmed that it is committed to promoting the rights of Palestine refugees. ${ }^{95}$ The allocated budget covers a sum of 287 million Euro. ${ }^{96}$ The EU and its member States propose, individually, additional financial support and contributions. ${ }^{97}$

Although the EU is not a strong actor at the political level in the Palestine/Israel question, it has occasionally interfered at different levels. Its instrument contributing to Stability and Peace, whose focus is peacebuilding, conflict prevention and response to emerging threats, is prevalent. The explicit policy of the EU has aimed at funding UNRWA and the Palestinian Authority. ${ }^{98}$ The EU's will to support UNRWA reflects its interest in keeping UNRWA within its functional mandate. This policy serves two aims: first, it secures that minimum humanitarian services are provided to Palestinian refugees. Secondly, it saves the EU legal, financial and political issues as it legally hinders Palestine refugees from seeking refuge in the EU countries.

There is no doubt that UNRWA has been providing for education, health, micro-finance and social services to Palestinians. Nonetheless, UNRWA's mandate is weak, powerless and at the mercy of political policies and financial contributions. Most importantly, as stated previously, the agency, due to its mandate, is unable to offer an adequate level of international protection to Palestine refugees. The exclusion under international conventions as EU Directive is actually built upon the very phenomenon of UNRWA. The idea of dismantling UNRWA would put the implementation of these exclusion provisions on hold. The EU and its member States are, obviously, interested in the continuation of the UNRWA. If for any reason, either political or financial, UNRWA's mandate is not renewed and the Agency abolished, legal consequences and implications would materialize. On the surface, the consequences seem small: UNHCR could take over the responsibility for Palestine refugees. However, the issue has much more complicated dimensions due to the peculiar situation of Palestine refugees and differences between the mandate of UNRWA and UNHCR. There are several legal implications that could be discussed in case UNRWA ceases to exist, two main implications are identified in this article. The first concerns the ipso facto application and the second concerns the implementation of basic human rights.

\subsection{Ipso Facto Application}

Article 1D of the 1951 Convention, in the second paragraph, has brought about the answer regarding situations when protection or assistance of persons, as identified in first paragraph, has ceased for any reason, these persons shall ipso facto be entitled to the benefits of this Convention. The EU Directive also answers the question in Article 12(1)(a), stating that:

\footnotetext{
${ }^{92} \mathrm{UN}(\mathrm{n} 67)$

${ }^{93}$ European Commission Implementing Decision of 28.11.2019, amending Commission Implementing Decision C (2018) 1271 of 23.2.2018 on the Multi- annual Action Programme for 2018, 2019 and 2020 in favour of Palestine from the general budget of the Union. Brussels, 28.11.2019 C (2019) 8754 final. Annex 2.

${ }^{94} \mathrm{Ibid}$

${ }^{95}$ Ibid

${ }^{96}$ Ibid

${ }^{97}$ UNRWA (2019). The European Union and Germany Sign Vital Contribution Agreements At UNRWA Jerusalem Girls' School In Silwan In East Jerusalem, Press Release, 11 December $2019<\mathrm{https} / /$ www.unrwa.org/newsroom/press-releases/european-union-and-germany-sign-vitalcontribution-agreements-unrwa> accessed 1 April 2021; European Commission - European Neighbourhood Policy and Enlargement Negotiations (2018). EU supports the activities of the United Nations Relief and Works Agency for Palestine Refugees in the Near East (UNRWA) with $€ 82$ million, EU Press Release, 15 March $2018<\mathrm{https} / / /$ ec.europa.eu/neighbourhood-enlargement/news_corner/news/eusupports-activities-united-nations-relief-and-works-agency-palestine-refugees_en> accessed 1 April 2021; European Commission (2018). The European Union proposes additional $€ 40$ million for Palestine Refugees to keep schools and health clinics open, EU Press Release 27 September $2018 \quad<$ https://ec.europa.eu/commission/presscorner/detail/en/IP_18_5911> accessed $1 \quad$ April 2021 $<$ https://eeas.europa.eu/delegations/palestine-occupied-palestinian-territory-west-bank-and-gaza-strip/83159/european-union-contributes-eur4-million-unrwa-covid-19-flash-appeal_en $\geq$ all accessed on 13 July 2020

98 European Neighborhood Policy and Enlargement Negotiations, 'Palestine' <https://ec.europa.eu/neighbourhoodenlargement/neighbourhood/countries/palestine_en $\geq$ accessed 20 August 2020
} 
"When such protection or assistance has ceased for any reason, without the position of such persons being definitely settled in accordance with the relevant resolutions adopted by the General Assembly of the United Nations, those persons shall ipso facto be entitled to the benefits of this Directive." 99

According to UNHCR, the phrase "ceased for any reason" in the second paragraph of Article 1D of the 1951 Convention/Article 12(1)(a) of the Qualification Directive "should not be construed restrictively". ${ }^{100}$ This phrase would include: "(i) the termination of UNRWA as an agency; (ii) the discontinuation of UNRWA's activities; or (iii) any objective reason outside the control of the person concerned such that the person is unable to (re-)avail themselves of the protection or assistance of UNRWA." 101 As demonstrated in the previous sections, the dismantling of UNRWA would place Palestine refugees under the protection of the Qualification Directive and the Conventions of 1951 and 1954, where the exclusion clauses of Article 12(1)(a) of the Qualification Directive, Article 1D of the 1951 Convention and Article 1(2)(i) of the 1954 Convention on Stateless Persons cease to apply.

The ipso facto protection that must be granted to Palestine refugees in accordance with Article 1D (2) of the 1951 Refugee Convention and Article 12(1)(a) of the Qualification Directive will have a huge impact, not only on Palestine refugees, but also on the whole international community. From a legal point of view, all states who ratified the 1951 must grant Palestine/Palestinian refugees, those who fell under the exclusion provision, the full protection named in the Convention in case of UNRWA dismantle. Likewise, the EU member States must grant the protection named in the Directive. Thus, Palestinians would benefit from such application and their situation could be assessed in accordance with their situation and given their historical plight. Within such application, Palestine/Palestinian refugees are enabled to exit their legal lacuna and join the minimal international protection available for all other refugee groups in the world. Overall, this means that the EU member States practices towards Palestinian refugees would and must differ. For instance, in respect of granting international and European protection status to Palestinians, this protection would be purely legal, related to the provisions of relevant international treaties and directed at the heart of the implementation of the EU Qualification Directive.

Those Palestinians who would seek refuge in Europe, would then ipso facto be entitled to refugee status. Similarly, Palestinian refugees already present in the EU, who have so far been denied a legal status, would have to be considered as refugees. Currently, many Palestinian refugees in the EU are not being granted the same rights as other refugees, while many have still remained in the EU without a legal status. ${ }^{102}$ With the application of the EU Qualification Directive, these Palestinians could seek for asylum without the burden to prove their particular status under the mandate of UNRWA.

\subsection{Implementation of Basic Human Rights}

As stated previously, due to the exclusion clauses, Palestinians are deprived form benefiting from the set of human rights and freedoms granted by the international and EU refugee regime. In other words, they are not enjoying the protection offered to other refugees in the world.

The services that UNRWA is providing will then have to be provided by the host States, placing them under a much bigger burden than it is currently the case. This concerns not only current host countries but also other countries, including EU member States. For example, if the States in the Middle East are not able to carry the burden alone - for example, Lebanon and Syria are obviously not in a good position to finance or support all Palestinian refugees, and they have never been or willing to do so - Palestinian refugees would find themselves in a necessity to seek for refuge in any country in the world, including the EU countries. Alternatively, Palestinians will suffer serious violations of their human and fundamental rights, which goes against the EU plan for peace and security in the region. The services that UNRWA currently provides would have to be transferred to the host countries and/or under the mandate of UNCHR. As the UNGA resolutions endorsing the rights of Palestine refugees are still valid, their rights would have to be guaranteed given their special status, specifically their right to return. It is, however, unclear how this could be realized.

Other basic services, - that are considered as basic human rights - which are protected by the UNRWA mandate, such as the right to education and health also must to be granted to Palestinian refugees in one way or another. Protection, respect and fulfilment of these rights generally fall under the obligation of the host country, as UNHCR

\footnotetext{
${ }^{99}$ EU Qualification Directive, art 12(1)(a)

${ }^{100}$ UNHCR - The UN Refugee Agency, Note on UNHCR's Interpretation of Article 1D of the 1951 Convention relating to the Status of Refugees and Article 12(1)(a) of the EU Qualification Directive in the context of Palestinian refugees seeking international protection (May 2013), 4

${ }^{101}$ Ibid

102 Akram and Rempel, ‘Temporary Protection' (n 17)
} 
only ensures, in addition to emergency assistance, that everyone has the right to seek asylum. Therefore, it seems probable that the reliance on international and regional human rights instruments will be much greater without UNRWA. ${ }^{103}$ These instruments include the Universal Declaration of Human Rights (UDHR), the International Covenant on Civil and Political Rights (ICCPR) and the International Covenant on Economic Social and Cultural Rights (ICESCR). The ICESCR, in Article 2, requires State Party to "take steps, individually and through international assistance and co-operation, especially economic and technical, to the maximum of its available resources, with a view to achieving progressively the full realization of the rights recognized in the present Covenant by all appropriate means..."104 The realization of these obligations must be implemented without discrimination whatsoever, which means that the rights of Palestinian refugees in these host countries must be protected, respected and fulfilled. This might actually be beneficial to those Palestinian refugees whose rights are not fully granted in some host countries. Host countries, more than now, would be under pressure to respect international human rights standards and grant these rights to all refugees. The EU, unquestionably, would be willing to channel millions of Euros to prevent such issues to reach the territories of its member States.

Finally, UNRWA largely employs Palestinian refugees in education, health, and other administrative tasks. UNRWA has over 30'000 employees, this includes a number of international employees, where the majority of which are Palestinian refugees. ${ }^{105}$ The dismantling of UNRWA would therefore also lead to a deterioration of the situation of those people, leaving thousands of employees jobless, millions of children without education, and millions of beneficiaries without healthcare or financial development. This, in return, would have a huge impact on the development of these refugees in the short and long terms. Most importantly, this would lead to the suffer of Palestinian refugees in the UNRWA areas. They would suffer from disastrous economic and social impairments. It would, inevitably, create a new wave of Palestinian refugees and migrants. It is crucial to note that UNRWA is participating to providing work opportunities to some of those refugees. Dismantle of UNRWA means that host countries are required to ensure the accomplishment of the right to work as stated in both the 1951 and 1954 Conventions.

\section{Conclusion}

The discussion of the consequences of a possible dismantling of UNRWA is significant. There is nothing that ensures a continuation of UNRWA's mandate, especially with all the financial, political and social obstacles at hand. However, the continuation of UNRWA's mandate is vital for more than five million Palestine/Palestinian refugees. A cessation of UNRWA means that these refugees ipso facto fall under the protection of the international refugee regime, and would, thus, have to be treated in the same way as all other refugees. Palestinians would no longer be singled out from the protection of international refugee law, and their basic and fundamental human rights and freedoms, which are necessary for their survival, would have to be guaranteed by other actors.

For Palestinians, dismantling UNRWA could, therefore, mean that the protection gap that they are currently facing will shrink or eventually disappear. The international community, including UNCHR, should search for durable solutions for Palestinians, in the same manner in which all other refugees are dealt with. It must be clear to the international community, including the EU, that abolishing UNRWA would impact and largely improve the legal situation of the concerned persons. Obviously, an improvement of the legal situation of Palestinians could also be accomplished without dismantling UNRWA. They could actually be placed under the mandate of UNCHR, with a continuation of the UNRWA mandate for humanitarian assistance. This might be legally complicated to realize but could be implemented through a General Assembly resolution. Instead of considering UNRWA as an organ or agency of the $\mathrm{UN}$, it could become an international organization with a special status.

In this event, the EU member States must deal with Palestine/Palestinian refugees in accordance with the EU Qualification Directive. This would entail that the discussed cases of Bolbol, El Kott, Alheto and XT cases would be no longer applicable or relevant to EU member States. However, this could allow Palestine/Palestinian refugees to seek for asylum and establish the basis of their cases without the burden to prove that UNRWA mandate does not apply to them. The cessation of UNRWA, hence, is a double-edged sword. In order to avoid serious humanitarian consequences on Palestine Refugees, UNRWA could only operate as a humanitarian agency, where Palestinians are placed under the protection of UNCHR with a guarantee of full international protection.

\footnotetext{
103 UN-OHCHR 'Fact Sheet No. 20, Human Rights and Refugees (July 1993) https:/www.ohchr.org/Documents/Publications/FactSheet20en.pdf> accessed 20 August 2020; see also UNHCR, 'Human Rights and Refugee Protection (RLD 5)' (October 1995) < https://www.unhcr.org/3ae6bd900.pdf > accessed 25 July 2020

104 International Covenant on Economic, Social and Cultural Rights of 1966 (Adopted and opened for signature, ratification and accession by General Assembly resolution 2200A (XXI) of 16 December 1966 entry into force 3 January 1976, in accordance with article 27), Article 2.1.

105 UNRWA, 'Working UNRWA'<https://www.unrwa.org/careers/working-unrwa> accessed 18 August 2020
} 


\section{References}

Alain, G. (2001). The European Union and the Refugee Question. In N. Aruri (Ed.), Palestinian Refugees: The Right of Return. Pluto Press.

Are, K. (2009). Widening the Protection Gap: The "Politics of Citizenship" for Palestinian Refugees in Lebanon, 1948-2008. Journal of Refugee Studies, 22, 51. https://doi.org/10.1093/jrs/fen047

Asem, K. (2009). Palestinian Refugees in Arab States: A Rights-Based Approach. Robert Schuman Centre for Advanced Studies - European University Institute. CARIM Research Reports 2009/08.

BADIL - Resource Center for Palestinian Residency \& Refugee Rights 'Survey of Palestinian Refugees and Internally Displaced Persons' (2016-2018 Vol IX, xiv).

Benny, M. (1999). Righteous Victims: A History of the Zionist-Arab Conflict 1881-1999. New York: Alfred A. Knopf, 340-343.

CJEU, case C-364/11, El Kott, ECLI: EU:C:2012:826. https://doi.org/10.1038/nrd3886

CJEU, case C-507/19, XT, ECLI: EU:C:2021:3.

CJEU, case C-585/16, Alheto, ECLI: EU:C:2018:5.

CJUE, case C-31/09, Bolbol, ECLI: EU:C:2010:351.

Convention Relating to the Status of Refugees of 1951.

Convention Relating to the Status of Stateless Persons of 1954.

Council Directive 2004/83/EC of 29 April 2004 on minimum standards for the qualification and status of third country nationals or stateless persons as refugees or as persons who otherwise need international protection and the content of the protection granted, OJ L 304, 30.9.2004.

Damian, L. (2018). UNRWA's Protection Mandate: Closing the Protection Gap. International Journal of Refugee Law, 30, 444. https://doi.org/10.1093/ijrl/eey055

Dina, K. (2021). Inclusion and citizenship: Syrian and Palestinian refugees in Lebanon. International Journal of Inclusive Education, 25(2), 283-297. https://doi.org/10.1080/13603116.2019.1707308

Directive 2011/95/EU of the European Parliament and of the Council of 13 December 2011 on standards for the qualification of third-country nationals or stateless persons as beneficiaries of international protection, for a uniform status for refugees or for persons eligible for subsidiary protection, and for the content of the protection granted, OJ L 337, 20.12.2011, p. 9-26.

Editorial, 'Explainer: Israel annexation and the West Bank’ BBC. (22 June 2020). Retrieved October 9, 2020, from https://www.bbc.com/news/world-middle-east-52756427

Editorial, 'Natanyahu says West Bank annexation pan still on the table' AL-JAZEERA. (13 August 2020). Retrieved October 9, 2020, from https://www.aljazeera.com/news/2020/08/netanyahu-west-bankannexation-plans-table-200813183431066.html

EUAS, European Union Contributes EUR 4 Million to UNRWA COVID-19 Flash Appeal, Jerusalem. (20 July 2020). Retrieved July 13, 2020, from https://eeas.europa.eu/delegations/palestine-occupied-palestinianterritory-west-bank-and-gaza-strip/83159/european-union-contributes-eur-4-million-unrwa-covid-19-flashappeal_en

European Commission - European Neighbourhood Policy and Enlargement Negotiations. (2018). EU supports the activities of the United Nations Relief and Works Agency for Palestine Refugees in the Near East (UNRWA) with €82 million, EU Press Release, 15 March 2018. Retrieved April 1, 2021, from https://ec.europa.eu/neighbourhood-enlargement/news_corner/news/eu-supports-activities-united-nationsrelief-and-works-agency-palestine-refugees_en

European Commission Implementing Decision of 28.11.2019, amending Commission Implementing Decision C. (2018). 1271 of 23.2.2018 on the Multi- annual Action Programme for 2018, 2019 and 2020 in favour of Palestine from the general budget of the Union. Brussels, 28.11.2019 C (2019) 8754 final. Annex 2.

European Commission. (2018). The European Union proposes additional $€ 40$ million for Palestine Refugees to keep schools and health clinics open, EU Press Release 27 September 2018. Retrieved April 1, 2021, from https://ec.europa.eu/commission/presscorner/detail/en/IP_18_5911

European Council, Venice Declaration on the Middle East. (12-13 June 1980). Retrieved October 9, 2020, from 
http://ec.europa.eu/external_relations/mepp/decl/index.htm

European Neighbourhood Policy and Enlargement Negotiations, 'Palestine'. Retrieved August 20, 2020, from https://ec.europa.eu/neighbourhood-enlargement/neighbourhood/countries/palestine_en

Executive Committee of the High Commissioner's Programme, Conclusion on International Protection No. 90 (LII) - 2001. (5 October 2001). No. 90 (LII), para (j). Retrieved July 9, 2020, from https://www.refworld.org/docid/3bd3e3024.html

Francesca, A. (2018). UNRWA and Palestine Refugee Rights: New Assaults, New Challenges. Institute for Palestine Studies, 11.

Heather, N. (2018, August). On U.S. Assistance to UNRWA, Press Statement. Retrieved July 6, 2020, from https://www.state.gov/on-u-s-assistance-to-unrwa/

Human Rights Watch. (2010). Stateless Again: Palestinian-Origin Jordanians Deprived of their Nationality. 1 February 2010. Retrieved January 19, 2021, from https://www.hrw.org/report/2010/02/01/statelessagain/palestinian-origin-jordanians-deprived-their-nationality

Ilan, G., \& Joseph, W. (1984). European political cooperation and the Palestinian-Israeli conflict: an Israeli perspective. In D. J. Allen, \& A. Pijpers (Eds.), European Foreign Policy Making and the Arab-Israeli Conflict (pp. 121-160). The Hague, Nijhoff.

Immigration and Refugee Board of Canada, "Kuwait and Palestine: residence status of stateless Palestinians, including access to employment, education, health care and other services, and the ability to travel in and out of the country; the requirements and procedures to renew residence status; treatment of stateless Palestinians whose residency status has expired (2015-November 2017)", 24 November 2017, ZZZ106021.E, available at: https://www.refworld.org/docid/5a84030f4.html> accessed 19 January 2021.

Immigration and Refugee Board of Canada, "Palestine and United Arab Emirates: residence status of stateless Palestinians, including access to employment, education, health care and other services, and the ability to travel in and out of the country; the requirements and procedures to renew residence status; treatment of stateless Palestinians whose residence status has expired (2015-November 2017)", 24 November 2017, ZZZ106014.E, available at: https://www.refworld.org/docid/5a8400294.html> accessed 19 January 2021.

International Covenant on Economic, Social and Cultural Rights of 1966 (Adopted and opened for signature, ratification and accession by General Assembly resolution 2200A (XXI) of 16 December 1966 entry into force 3 January 1976, in accordance with article 27.

Israeli-Palestinian Interim Agreement on the West Bank and the Gaza Strip (Oslo II), 28 September 1995.

Lance, B. (2009). The Mandate of UNRWA at Sixty. Refugee Survey Quarterly, 28, 452-454. https://doi.org/10.1093/rsq/hdp033

Law No. 6 of 1954 on Nationality (last amended 1987) [], 1 January 1954 (Kingdom of Jordan).

Lex, T. (1998). The Status of Palestinian Refugees in International Law (1st ed.) Clarendon Press.

Lex, T., \& Francesca, A. (2020). Palestinian Refugees in International Law (2nd ed.). Oxford University Press. https://doi.org/10.1093/law/9780198784043.001.0001

Neil, G. (2006). Negotiating Rights: Palestinian Refugees and the Protection Gap. Anthropological Quarterly, 79, 717. https://doi.org/10.1353/anq.2006.0049

Noura, E. (2014). Palestinian Refugees and the Syrian Uprising: Filling the Protection Gap during Secondary Forced Displacement. International Journal of Refugee Law, 26, 581. https://doi.org/10.1093/ijrl/eeu047

Palestinian Central Bureau of Statistics, 'About 13.5 Million Palestinians in the Historical Palestine and Diaspora'. (11 July 2020). Retrieved October 9, 2020, from http://pcbs.gov.ps/post.aspx?lang=en\&ItemID=3774

Susan, A., \& Nidal, A.-A. (Eds.). (2015). Closing Protection Gaps: A Handbook on Protection of Palestinian Refugees in States Signatories to the 1951 Refugee Convention (2nd ed.). BADIL Resource Center for Palestinian Residency and Refugee Rights.

Susan, M. A. (2002). Palestinian Refugees and Their Legal Status: Rights, Politics, and Implications for a Just Solution. Journal of Palestine Studies, 31, 36. https://doi.org/10.1525/jps.2002.31.3.36

Susan, M. A. (2014). UNRWA and Palestinian Refugees. In E. Fiddian-Qasmiyeh et al. (Eds.), The Oxford Handbook of Refugee and Forced Migration Studies. Oxford University Press. 
Susan, M. A., \& Terry, R. (2004). Temporary Protection as an Instrument for Implementing the Right of Return for Palestinian Refugees. Boston University International Law Journal, 22, 1.

SwissInfo.ch, 'Questions raised over UNRWA after Swiss-Israeli meeting. Retrieved October 9, 2020, from https://www.swissinfo.ch/eng/palestinian-refugee-agency_questions-raised-over-unwra-after-swiss-israelimeeting $/ 45210084$

Terry, R. (2020). The United Nations Conciliation Commission for Palestine, Protection, and a Durable Solution for Palestinian Refugees. Badil-Information and discussion Brief, (5).

The European Union, 'The history of the European Union'. (30 April, 2020). Retrieved July 28, 2020, from https://europa.eu/european-union/about-eu/history_en

UN 'UNRWA Faces Greatest Financial Crisis in its History Following 2018 funding Cuts, Commissioner-General Tells Fourth Committee- Press Release'. (9 November, 2019). Retrieved July 12, 2020, from https://www.un.org/unispal/document/unrwa-faces-greatest-financial-crisis-in-its-history-following-2018funding-cuts-commissioner $\% \mathrm{E} 2 \% 80 \% 91$ general-tells-fourth-committee-press-release/

UNGA 'Special Political and Decolonization Committee- Fourth Committee' UNRWA 74th Session. UN Doc. A/C.4/74/L.10. (11 November, 2019).

UNGA Res 181 (II) (29 November 1947) UN Doc A/RES/181 (II).

UNGA Res 194-III (11 December 1948) UN Doc A/RES/194 (III). https://doi.org/10.17723/aarc.11.3.mu61731t6268317k

UNGA Res 2252 (ES-V) (4 July 1967) UN Doc A/RES/2252 (ES-V).

UNGA Res 2535 (XXIV) (10 December 1969) UN Doc A/RES/2535(XXIV)A-C

UNGA Res 2792 (XXVI) (6 December 1971) UN Doc A/RES/2792(XXVI)A-E

UNGA Res 2963 (XXVII) (13 December 1972) UN Doc A/RES/2963(XXVII)A-F

UNGA Res 302- IV (8 December 1949) UN Doc A/RES/302 (IV).

UNGA Res 393-V (2 December 1950) UN Doc A/RES/393 (V).

UNGA Res 513-VI (6 January 1952) UN Doc A/RES/513(VI).

UNGA Res 70/85 (9 December 2015) UN Doc A/RES/70/85. https://doi.org/10.1016/j.appet.2014.11.014

UNGA Res 71/93 (6 December 2016) UN Doc A/RES/71/93. https://doi.org/10.1002/wea.2679

UNGA Res 72/82 (7 December 2017) UN Doc A/RES/72/82.

UNGA Res 74/L.13 (11 November 2019) UN Doc A/C.4/74/L.13. https://doi.org/10.3917/mem.074.0013

UNHCR - The UN Refugee Agency, Note on UNHCR's Interpretation of Article 1D of the 1951 Convention relating to the Status of Refugees and Article 12(1)(a) of the EU Qualification Directive in the context of Palestinian refugees seeking international protection. (May, 2013).

UNHCR 'Global Trends: Forced Displacement in 2019'. (2020). Retrieved October 9, 2020, from https://www.unhcr.org/globaltrends2019/

UNHCR, 'Human Rights and Refugee Protection (RLD 5)'. (October 1995). Retrieved July 25, 2020, from https://www.unhcr.org/3ae6bd900.pdf

United Nations. (2008). The Question of Palestine and the United Nation. New York, the United Nations Department of Public Information.

UN-OHCHR 'Fact Sheet No. 20, Human Rights and Refugees. (July, 1993). Retrieved August 20, 2020, from https://www.ohchr.org/Documents/Publications/FactSheet20en.pdf

UNRWA ‘Palestine Refugees' Retrieved October 9, 2020, from https://www.unrwa.org/palestine-refugees

UNRWA, 'Eligibility Registration'. Retrieved October 9, 2020, from https:/www.unrwa.org/what-wedo/eligibility-registration

UNRWA, 'Medium-Term Strategy 2016-2021' (UNRWA 2016) 30.

UNRWA, 'Protection Division'. Retrieved August 2, 2020, from https://www.unrwa.org/protection-division

UNRWA, 'UNRWA appeals financial and political support at the General Assembly's Fourth Committee- Press Release. (13 November 2019). Retrieved August 10, 2020, from https://www.unrwa.org/newsroom/press- 
releases/unrwa-appeals-financial-and-political-support-general-assembly $\% \mathrm{E} 2 \% 80 \% 99 \mathrm{~s}$-fourth

UNRWA, 'What do we do: protection'. Retrieved August 9, 2020, from https://www.unrwa.org/what-wedo/protection

UNRWA, 'What we do'. Retrieved October 9, 2020, from https://www.unrwa.org/what-we-do

UNRWA, 'Who we are'. Retrieved July 20, 2020, from https://www.unrwa.org/who-we-are

UNRWA, 'Working UNRWA'. Retrieved August 18, 2020, from https://www.unrwa.org/careers/working-unrwa

UNRWA. (2019). The European Union and Germany Sign Vital Contribution Agreements at UNRWA Jerusalem Girls' School In Silwan In East Jerusalem Press Release, 11 December 2019. Retrieved April 1, 2021, from https://www.unrwa.org/newsroom/press-releases/european-union-and-germany-sign-vital-contributionagreements-unrwa

William Dale. (1974). UNRWA - A Subsidiary Organ of the United Nations. International and Comparative Law Quarterly, 23, 576, 579. https://doi.org/10.1093/iclqaj/23.3.576

\section{Copyrights}

Copyright for this article is retained by the author(s), with first publication rights granted to the journal.

This is an open-access article distributed under the terms and conditions of the Creative Commons Attribution license (http://creativecommons.org/licenses/by/4.0/). 